\title{
African Library Information Services and Contribution to Sustainable Development: A Perception Paper
}

\author{
Rosemary M. Shafack ${ }^{1}$ \\ ${ }^{1}$ University of Buea, Buea, Cameroon \\ Correspondence: Rosemary M. Shafack, University of Buea, Buea, P.O Box 63, South West Region, Cameroon. \\ E-mail: roshafack@gmail.com
}

Received: February 14, 2020

Accepted: March 1, $2020 \quad$ Online Published: March 30, 2020

doi:10.5539/jsd.v13n2p126

URL: https://doi.org/10.5539/jsd.v13n2p126

\begin{abstract}
One of the main challenges of every society is how to gain access to authentic, quality and trustworthy information for the proper functioning of the various sectors of society. Every human being needs one type of information or the other to meet their varying needs in order to function properly. Information is an enabler of the acquisition of skills and knowledge for sustainable livelihood. This is evident in that access to information has been considered a fundamental human right and supported by many organizations such as, the International Federation of Library Associations and Institutions (IFLA). It is obviously clear that, there can be no sustainable development without access to information and there can be no meaningful inclusive access to information without libraries, a view supported by outstanding leaders of the information profession. Libraries have proven to drive the knowledge economy which constitutes an indicator of sustainability. As such, they have been so well structured into types in a way that covers all segments of the human society. There is no single individual whose information needs cannot therefore be catered for by one type of library or the other. Library services, therefore, are indispensable in all aspects of the human community. This paper ignites discussions on the contributions of the African library services in supporting individual citizens, communities, institutions and economies in order to improve livelihood and quality of life in a sustainable way. In partnership with governments, well-functioning African library services can contribute to sustainable development through education, literacy, health, economy, ensuring equality, social justice, cultural growth, and good governance. This is, certainly, needed to help build a resilient African society, the Africa we want, through sustainable development.
\end{abstract}

Keywords: African library, information services, sustainable development

\section{Introduction}

The world faces immense challenges which range from people living in poverty and denied dignity, rising inequalities, unemployment, global health threats, natural disasters, spiraling conflicts, violent extremism, terrorism and related humanitarian crises leading to force displacement of people, just to name these. These problems have challenged the world's bodies to think and reflect on a way forward. Some of these ways include the UN Sustainable Development Agenda, the African Union Agenda 2063 and the national development plans. These agendas require a number of stakeholders to intervene if these challenges must be reduced for the benefit of humanity. One of such stakeholders is the Library and Information Science (LIS) Profession (Shafack, 2016). The question that comes up is whether the African library information services are able to contribute to the reduction of the challenges listed and many more? This paper tries to ignite a conversation on this very important subject of sustainable development and the role of African libraries.

Information plays a vital and indispensable role in the socio-economic development of a nation (Srikanth, 2017). It has been propounded, agreed and documented that access to information is a fundamental human right. Therefore, any individual who is unable to find and use needed information in an appropriate and effective manner will not be able to progress or achieve his or her goals. Access to information facilitates the all-round development of every individual, thus it is just right to make it a fundamental human right. This view is supported by Srikanth (2017) who holds that, citizens' capability to use available information in an effective manner to attain their goals is a key factor and assumes great significance in development.

The place of information in development cannot be overemphasized as world bodies have highlighted the place of information in development. The European Union presidency in 2001 suggested for sustainable development, 
four priority areas and all are underpinned on information (Akam, 2011). These included the following: firstly, the collection and dissemination of information; secondly, indicators for sustainable development, having as important tools especially to reduce the complexity of information and provide complex information on sustainable development; thirdly, Information access and participation of the public, considering the active participation of the civil society in general; and fourthly and lastly, the role of private companies in information provision for sustainable development.

The above highlights the role information plays in the development of society. Information drives the knowledge economy and must be handled with the care it deserves by appropriate information services which are no other than libraries and related information services in society. Librarianship is a service-oriented profession and focuses on the management of appropriate and relevant information resources to meet diverse needs of all humans. This is evident in the existence of the various types of libraries whose structures are well designed to meet the information needs of all segments of the human society.

The UNESCO and IFLA manifesto for each library type goes further to provide the base for their functions so that they can adequately meet the needs of all and sundry in a sustainable way; providing them with information literacy skills for life long use. This goes to support the goals of librarianship, particularly its role in the transmission of knowledge which cannot be achieved without users occupying a huge proportion in the process of information services and has implications for how librarianship is and will be practiced including its service delivery (Waseye, Busulyi \& Tunde, 2016).

If libraries must justify their existence then their service delivery should drive the knowledge economy in a way that will provide skills and knowledge to humans in a sustainable way for appropriate livelihood. This is an indication that the information profession today demands much more critical thoughts and efforts in connecting with users and maintaining a good relationship and this has been facilitated by technological and societal changes (Cheong, 2008). African libraries cannot therefore afford to be left out in this process if they must contribute to the development of the Africa we want and within the time lines of the sustainable development agendas.

\section{The Problem}

The role of libraries in information delivery has been changing as a result of the information overload with its availability in variant formats and the fast-changing technological environment. The $21^{\text {st }}$ century has brought a lot of changes and continue to do so not only on the library and information services but equally on the roles and expectations of librarians and in all other information professionals (Kumar, 2016). The information profession experiences new challenges following unprecedented explosion of information in varying forms and formats and the application of information communication and mobile technologies in generating, disseminating and providing access to information. These challenges are evidently more critical for the African libraries that have challenges that are unique to them in addition to the generic challenges of information explosion and compounded by the fast-changing arena of the information and communications technologies (ICTs).

If African libraries must provide information services that make them the expected motors of change in enhancing sustainable development, then the professional must change from just being custodians of information resources to information resources content managers taking advantage of the appropriate technological skills to meet the needs of the $21^{\text {st }}$ century information user especially the younger generation. This paper is therefore out to ignite discussions on questions on; whether the African library information services are able to contribute in supporting individual citizens, communities, institutions, and economies to provide livelihood and quality living in a sustainable way?

\section{Literature Review}

A number of scholars have expressed concerns on the fundamentals of libraries as repositories and managers of information critical in the development process. Buckland argues and rightly so that every society is an information society and the wider use of documents facilitated by new technologies, have made our societies particularly information intensive. This statement highlights even more the role libraries need to play in the society. The unprecedented explosion of information in varying forms and formats calls for mentorship on how to locate what is needed to meet information needs. This is supported by Alemna (2012) who states that, the world's intellectual output would be useless or even constitute a nuisance, if libraries were not there to gather, analyze, classify, catalogue and facilitate access to them.

Library information services are tools for human development for they increase people's chances to acquire knowledge and have access to information resources that would enable a healthy, gainful and dignifying life 
(United Nations Educational, Scientific and Cultural Organization [UNESCO], 2000). This speaks to the five Ps of the United Nations Sustainable Goals with a focus on:

1) People: The wellbeing of all people

2) Planet: protection of the earth's ecosystems

3) Prosperity: Continued economic and technological development

4) Peace: Security and peace and

5) Partnership: Improving international cooperation

The above five aspects are interdependent and demand an integrated approach. The unifying factor in integrated thinking and approach is information. Information is a key input into the creation and maturation of knowledge and thus a significant criterion for growing a healthy society is access to information by all for all societal endeavours (Adu, 2012). Libraries constitute the engines that drive access to knowledge and therefore bringing about change and transformation.

Knowledge is fundamental to all spheres of life and critical for the growth of society (Tise, 2009). Today, libraries are associated with information collection, organization, dissemination and retrieval, all of which serve as a foundation for knowledge growth that results in literacy. Libraries are actually catalysts for human progress as they aid the development and transformation of knowledge and culture. They foster civic awareness in support of democracy and provide the resources for the development of economic productivity and innovation in society (Amonoo \& Azubuike, 2005).

The above respond to the UN SDGs, 8, 9 and 11 specifically. Thus, the role of libraries is very clear and their information services should be developed to actually target the achievement of specific development goals. African library information services need to be evaluated to see how well they are faring. This will help to highlight how much of refocusing is needed for their information services to align with the appropriate sustainable development goals that can bring the transformation of all sectors of society that will move the continent to the Africa we want. In aligning with the UN SDGs, African libraries have to ensure that the African Union Agenda 2063 as well as national development plans are taken into consideration. This is made clearer when the 7 aspirations of the Africa Agenda 2063 are given a closer view. In line with these aspirations, African libraries information services need to contribute to:

1) A prosperous Africa based on inclusive growth and sustainable development

2) An integrated continent politically united based on the ideals of Pan Africanism and the vision of Africa's Renaissance

3) An Africa of good governance, democracy, respect for human rights, justice and rule of law

4) A peaceful and secure Africa

5) An Africa with a strong cultural identity, common heritage, values and ethics

6) An Africa whose development is people driven, relying on the potential of African people, especially its women and youth and carrying for children and

7) Africa as a strong united, resilient and influential global player and partner (Africa Union Agenda 2063, 2015).

It is obvious that for libraries to be successful and effective, they cannot act alone. They need to build strong associations, partnerships and networks with strong, attractive and achievable plans of actions that they can use to advocate for substantial and sustainable support. Libraries need to advocate decision making at local, regional, national and international levels that can help bring about a change in polices in support of libraries. Libraries in many parts of the world have been seen as great agents of change based on what they have been able to deliver and, as a result, are receiving support from governments and other agencies and stakeholders. African libraries can follow the same steps by proving that they can be true agents of transformation of the communities. Libraries are of great value especially as development is concerned. This view has been supported by declarations such as that of Scheeder (2017) who stated that, there can be no sustainable development without access to information and there can be no meaningful inclusive access to information without libraries.

The great news is that most regions in the world recognize that sustainable development is based on quality, reliable and appropriate information and the African LIS profession has equally recognized the key role libraries can play in achieving sustainable development as seen in the impact of the Cape Town Declaration and in the improvement recorded in the information service delivery across the continent. In these circumstances therefore, 
the questions for reflection include; whether, African libraries are currently doing enough to bring about transformation of communities? Are there major professional challenges that need urgent and immediate attention? How can African libraries forge ahead quickly and easily to be near the wave length of the rest of the world? Before answers to these questions are attempted, it is also important to reflect on the current level of operation of Africa's LIS profession.

\section{Current Level of Operation of Africa's LIS Profession}

It is worthwhile reflecting on the current state of operation of Africa's LIS profession. It is important that while we look at challenges, we should equally appreciate the progress that is being made. This will help build the steam for the LIS profession to forge ahead. The views mooted are very skeletal and in no way represent exactly what is going on, on the continent. These will stimulate professionals to take stock of their information service delivery and see how well they are aligning with their community development goals. Some of the steps already being taken include amongst others what has been reflected succinctly below. There is no doubt that while there are a host of challenges there are equally glimpses of hope.

The need for library education to take into consideration the changing ICT environment has been ongoing in many library schools with evidence of new programmes and research areas that have continuously reflected this reality. Examples include, subjects such as social informatics, data management, information architecture and digital libraries that are now being taught. Although most library training schools in Africa have not directly embraced the terminology of iSchools, they appear to be silently tilting towards its philosophy in response to information provision and knowledge management in digital environments. Essentially, common trends are noted in the growth of LIS schools, the review and revision of curricula and increased use of ICTs (Nalumaga, 2016).

There are formal discussions engaging the policy makers on the continent to integrate libraries in the development agendas, seen with the Cape Town Declaration (August,2015) and the follow up meeting in Durban (June, 2018). This level of discussion and engagement is bringing great hope to the LIS profession on the continent.

The continental association, AfLIA is driving the LIS profession and taking it to a very high level (The African Union) with the goal of having libraries placed on the African countries' government agendas. AfLIA is equally in partnership with several International organizations, building the skills of young professionals and making them sustainable for the LIS profession of today and tomorrow. This is quite promising not only for the sustainability of the future of the LIS profession but also for its quality to be able to bring about transformation for sustainable development to help achieve, 'The Africa We Want'.

Quite a few meetings and workshops have been initiated and sponsored by IFLA to sensitize and build skills not only for LIS professionals but equally to sensitize governments on the role libraries can play in enhancing sustainable development and the response has been great. This is laying a strong foundation for libraries to be confident in their roles as motors of change in their communities. The above and more have left the LIS profession with high spirits and that is the reason why we continue to be strong. We therefore urge professionals to take stock and reposition their information service delivery in ways that can align with the sustainable development goals of their communities.

\section{Challenges}

There is no doubt that while there are glimpses of hope, there are equally a host of challenges which needs a reflection on how to enhance the effectiveness and efficiency of African libraries in contributing to inclusive growth and sustainable development of the continent. Some of these challenges are discussed below as follows.

The world is changing quite fast and this is adding more challenges to the already existing challenges facing the library and information (LIS) profession. Generally, the African LIS profession is confronted daily by the effects of globalization, technological developments, economic growth factors, dwindling funds and number of younger professionals, fast changing information skills, just to name these. The profession is experiencing very few young people who are willing to go to LIS schools. While the older professionals are retiring, very few young ones are available to replace them. The older ones who are still in service are faced with the challenge of having redundant skills and are either reluctant to get involved in literacy programmes to upgrade their skills or there are no programmes available for them to do so. The LIS schools are yet to see the need to inculcate short training programmes to refresh the skills of in-service professionals.

It is evident that most LIS schools in Africa have not kept abreast with the rapidly changing digital environment (Bernett, 2013). The result of this is the production of young professionals lacking appropriate technological 
skills that are a must in information service delivery in modern libraries. Libraries in the $21^{\text {st }}$ century are all obliged to incorporate e-library services in order to cope with current trends. The younger generation are prone to using e-resources and gradually less of analogue where they are available. Most of the major developments in libraries include; online communication, mobile technology, social media application, digital curation and preservation, to name just these; in order to fit into this new landscape, the LIS professionals have to take on new roles that demand new skills.

Besides, libraries need transformation of their structures, infrastructure, facilities and connect to Internet to cope with the new dispensation (Jain, 2016). In the face of this, the LIS professionals have no alternative given that the upsurge in information and communications technologies (ICTs) has brought a lot of changes in the management of knowledge and how libraries are driving accessibility to it.

The impact of technology has resulted in the proliferation of large-scale digital libraries, multimedia information systems and Internet resources and services. This has, in turn, contributed to the phenomenal increase in the amount of knowledge available in any given discipline and libraries are confronted with an information overload. There is therefore a lot of technological skills, infrastructure and facilities needed to cope with all of these from the point of view of information service delivery.

The issue of gaining government dedicated support for libraries specially to invest in costly areas such as ICT infrastructure, bandwidth, training and staffing remains a major challenge for many African libraries. Many governments are feet-dragging in prioritizing support for library development on their agendas and this has left libraries weak and unsustainable. Notwithstanding all the challenges that may stand on the path of African library service delivery, African LIS professionals need to reposition themselves to drive access more forcefully and integrate new and emerging technologies and tools so as to contribute to sustainable development in a more meaningful way (Adu, 2012).

\section{Way Forward}

Even though plagued by a host of challenges discussed above, there are possibilities of improving African library service delivery for far reaching transformation effects. Some of the ways of achieving this would include:

1) There is the urgent need for African libraries to develop information literacy programmes that can help reduce the level of information illiteracy in the communities as much as possible.

2) There is the obligation of adopting and integrating new and emerging technologies and tools into traditional library settings to help drive access in a more sustainable way. In addition, the management of analogue information collections need to be automated in order to facilitate easy access to information resources. This will enable information users to have electronic sourcing tools such as the Online Public Access catalogue (OPAC) which is more fluid unlike the traditional analogue version. Moreover, OPAC has an outstanding advantage of being hosted on the internet, thus making information resource sourcing accessible from all parts of the world.

3) Most importantly, the African LIS schools need to align their content to current trends in the profession so as to graduate professionals with requisite skills that can cope with changing trends.

4) The question of advocating governments and other stakeholders of the profession is not optional but an aspect to be integrated into the strategic plans of libraries. Appropriate advocacy programmes need to be developed with qualified staff to execute them. Advocacy is a critical and professional activity and needs to be well crafted. When successful, the results can bring meaningful transformation.

5) There is a need for libraries to build partnerships and networks. This can be the building of consortia. Through consortia, libraries can build strong virtual collections and be able to sustain them. Through consortia, what an individual library cannot achieve can be greatly achieved and sustainably. Consortia usually put in place a number of projects that can be jointly achieved as a result of the cost. One of such is training. The skills of professionals can receive up-grading frequently when funds are pulled together and experts can easily be hired for training.

If African libraries can engage in some of these measures among others, there is no doubt that they will be able to bring transformation for development in their communities.

\section{Conclusion}

The place of information in development cannot be overemphasized. Thus, indeed, there cannot be any sustainable development without access to information and there cannot be any meaningful inclusive access to information without libraries (Scheeda, 2017). It is therefore clear that libraries are critical in driving access to information and in an inclusive manner in a way that no other organ in the human society can. African libraries 
should candidly reposition and equip themselves in order to effectively play this important role.

\section{References}

Adebayo, J. O., Akole, O. B., \& Salau, I. T. (2016). Core values of librarianship and practice of information ethics by librarians in four higher institutions in Oyo Ste, Nigeria. Library Philosophy and Practice. Retrieved from http://digital commons.unl.edu/libphil/prac

Adu, T. L. (2012). Libraries driving access to knowledge. Ghana Library Journal, 24(1), 35-55.

African Union. (2015). African Union development agenda 2063. Addis Ababa: African Union.

Akam, N. (2011). Information for sustainable development in society under competitiveness rule: A socialist market attitude. Cahier d'outre-mer. https://doi.org/10.4000/com.6231

Alemna, A. A. (2012). Libraries: Key to key to national development. Ghana Library Journal, 24(1), 1-8.

Amonoo, P., \& Azubuike, A. (2005). Libraries and the information society in Africa. World submit on the information society. Tunis: UNECA, p. 1-4.

Bernett, P. (2013). Challenges and problems of library and information science education in selected African countries. Retrieved April 8, 2019, from http://creativecommons.org/licenses/by/3.0/

Buckland, M. (2017). A Short information account of your ever-increasing dependence on a complex multiplicity of messages, records, documents and data. b\&w.: Illus.

Cheong, C. F. (2008). Librarianship. What is it about now? LAS Conference 2008: Innovative to Serve. 8=9 May.

Jain, P. (2016). Challenges of $21^{\text {st }}$ century academic libraries in Africa. African Journal of Library, Archives and Information Science, 26(2).

Kumar, P. K. S. (2016). Role of library and information science professionals in the knowledge society. Journal of Information Conscientia Beam, 2(2), 10-17. https://doi.org/10.18488/journal.104/2016.2.2/104.2.10.17

Nalumaga, R. (2016). iSchools and Africa: Trends and developments. Wiley On-Line Library.

Scheeda, D. (2017). Libraries and sustainable development. United Nations Dag Hammarskjold Library.

Srikanth, C. (2017). Role of public libraries: Information literacy in information society. IMACT: International Journal of research in Humanities, Arts and Literature, 5(7), 55-60.

UNESCO. (2000). Change and continuity: Concepts and tools for cultural approach to development. Paris: UNESCO.

\section{Copyrights}

Copyright for this article is retained by the author(s), with first publication rights granted to the journal.

This is an open-access article distributed under the terms and conditions of the Creative Commons Attribution license (http://creativecommons.org/licenses/by/4.0/). 